\title{
O projeto museográfico da exposição Cartografia de uma história - São Paulo colonial: mapas e relatos
}

\begin{abstract}
Ricardo Nogueira Bogus ${ }^{1}$
RESUMO: Este artigo apresenta o projeto museográfico da exposição Cartografia de uma história, inaugurada no Museu Paulista da Universidade de São Paulo em março de 2005. 0 projeto museográfico foi concebido e elaborado a partir do diálogo entre as propostas da equipe de pesquisa e os dados do perfil dos visitantes do Museu, constituindo-se assim um trabalho integrado, que buscava tratar de forma lúdica o ato de descobrir.

PALAVRAS-CHAVE: Cartografia histórica. Exposição. Projeto museográfico. Museu Paulista.
\end{abstract}

ABSTRACT: This article presents the museum set design project for Cartography of a history, an exhibition opened at Museu Paulista/São Paulo University in March 2005. The said project was conceived and developed based on a combination of the research team's ideas and the profile of visitors to the Museum. It is therefore an integrated pursuit whose purpose was to approach the process of discovery in a playful manner.

KEYWORDS: Historical cartography. Exhibition. Museum set design project. Museu Paulista.

Museu Paulista é um dos ícones da cidade de São Paulo, um edifício-monumento vinculado ao local da proclamação da Independência do Brasil, localizado em um sítio tão poderoso que impôs o nome pelo qual o museu é reconhecido até hoje: Museu do lpiranga. O seu saguão de recepção ao visitante é impactante, assim como sua escadaria, o que impede, mesmo que se quisesse, a possibilidade de ignorá-lo. Decididamente, não é possível a seu corpo curatorial trabalhar em um "cubo branco", um daqueles espaços neutros tão em voga no mundo da arte contemporânea, comumente construídos para receber exposições, tentando isolá-las do mundo exterior. $\bigcirc$ edifício e suas simbologias tomam parte das exposições e, a cada novo projeto, temos buscado aprofundar o diálogo entre arquitetura e museografia, intervindo visualmente com assumido
1. Museólogo, especialista em projetos de exposição do Museu Paulista da USP. E-mail: <rnbogus@usp.br>. 
1. Cf. Susan Pearce (1990, p. 135).

2. Cf. Waldisa Rússio (1981, p. 58).

3. Cf. Donald Horne (1992, p. 63). cuidado e aproveitando as possibilidades que o edifício, pelo seu porte e suas características, oferece.

A museografia da exposição Cartografia de uma história foi não só integrada ao projeto de pesquisa que a sugeriu, mas também ao processo de comunicação estabelecido entre os profissionais do museu e a pessoa visitante. Assim, os conceitos da pesquisa não foram passados apenas através do acervo selecionado e dos textos especialmente elaborados, mas incluíram a maneira como foram expostos, a exploração da espacialidade e a interatividade permitidas pelo contato com o objeto real, somadas às cores, às luzes e aos sons, envolvendo e dirigindo os sentidos e o olhar. Tecnologias atuais, como vídeo, informática instalados dentro do espaço expositivo e embricados no conceito e no roteiro tornaram-se elementos integrados à museografia. A exposição permitiu, justamente, esta experiência espacial e sensorial, em que o visitante recebe nossa mensagem perambulando pelas salas e, com sua formação e suas expectativas, a reelabora, criando - e levando-a ao partir - a sua leitura da exposição. Susan Pearce frisa que o significado do objeto "encontra-se não todo na própria peça, não todo em sua imaginação, mas em [um] lugar entre os dois. O objeto só toma vida ou significado quando o observador coloca [nele] sua imaginação e isso depende parcialmente de sua disposição e experiência e parcialmente do conteúdo do objeto que o provoca, é esta interação que cria significado"l .

Como disse Waldisa Rússio, o fato museal ou museológico constitui-se a partir de "Relação profunda entre o homem, sujeito que conhece, e o objeto, parte de uma realidade da qual o homem também participa, num cenário institucionalizado, o museu" ${ }^{2}$. Em uma visita ao museu, que pode ser individual ou compartilhada com parentes, com amigos ou colegas, é estabelecida uma relação direta, sem intermediários.

O projeto museográfico foi elaborado buscando concretizar o processo de comunicação entre as propostas da equipe de pesquisa e os públicos que a visitam. Comunicação a que podemos atribuir um sentido lúdico, o ato de descobrir. Falar em público, no nosso caso, com 400 mil visitantes ao ano, seria quase uma blasfêmia. Recebemos pessoas dos muitos segmentos que compõem nossa sociedade, de todas as idades e etnias, além de turistas de várias origens. Pessoas tão diferentes, com formações, experiências e expectativas tão diversas, que é instigante (e ao mesmo tempo enlouquecedor) imaginar os significados que serão construídos. $\bigcirc$ respeito aos públicos exige aceitarmos que existem diferentes níveis de leitura de uma exposição e, de qualquer maneira, a visita a uma exposição com caráter histórico é um ato cultural que possibilita a uma pessoa ampliar o seu sentido de tempo e espaço, ampliar seu repertório visual e seus horizontes, despertar curiosidades e criar necessidades de conhecimento. Segundo Donald Horne: "Nós somos muitos públicos e não somos passivos, somos participantes, nós abordamos o museu nos nossos termos" 3 .

No caso do Museu Paulista, um museu de história, este diálogo se torna fluente, lidamos com pessoas que conhecem o assunto do museu - história de São Paulo e do Brasil - aprendido na escola, nos monumentos espalhados pelas 
cidades, inclusive através dos nomes de ruas e rodovias, ou, pelo menos, dos meios de comunicação de massa, nos jornais, rádios e televisões, nas novelas de temáticas históricas, nos programas investigativos.

\section{Questões concretas}

Padronizar alguns elementos e diferenciar outros foram respostas que encontramos para facilitar ao visitante a leitura das exposições em um espaço constituído por salas sem interligação direta, que, no ir e vir, utilizam o mesmo corredor.

Todos os textos e legendas foram compostos com o mesmo tipo de letra, seguindo um mesmo padrão quanto aos dados a serem apresentados.

Diferenciar as cores das paredes das salas - antes pintadas todas na mesma cor creme - foi a maneira de demarcar a abrangência dos temas. Utilizamos a cor - o elemento envoltório - para sensibilizar o visitante quanto ao tema tratado. No geral, a cor utilizada na parede (ou uma cor coadjuvante) é também aplicada nas áreas externas e internas de vitrines, suportes de objetos e, ainda, como cor de fundo dos textos e legendas, com o objetivo de uniformizar o ambiente e, em consequência, destacar o acervo em exposição para, através do jogo das cores (os claros e escuros), valorizar certos objetos, elementos ou conceitos.

\section{A Exposição}

projeto museográfico para a exposição Cartografia de uma história - São Paulo colonial: mapas e relatos foi desenvolvido seguindo conceitos e padrões que estamos adotando para todas as exposições desenvolvidas no Museu Paulista, tendo seu projeto de museografia e a programação visual da exposição sido elaborado pelos comunicadores visuais Christine May Kauffmann Fidalgo e Rodrigo de Freitas, e por mim, museólogo, com a colaboração, na etapa final, de Maria Luísa Clapis, estagiária no setor.

Aspectos gerais

As cores: as salas foram coloridas seguindo os conceitos dos temas de cada espaço e a necessidade de criar uma divisão clara entre elas. As salas com temas que possibilitavam um envolvimento sensorial maior foram pintadas com cores marcantes - o azul e o verde; as salas com temas mais analíticos foram mantidas nas cores creme e ocre, neutras. Na sala da cosmografia, mergulhou-se no azul do mar. $\bigcirc$ verde das florestas envolveu a sala do engenheiro militar em campo; e, na sala das vivências, predominaram cores do sertão. $\bigcirc$ tom ocre 
marcou a sala sobre o uso político dos mapas; e o creme caracterizou a sala sobre o território em rede. O som: foram sonorizadas as salas cujos temas possibilitavam um envolvimento sensorial maior.

O lúdico: em diferentes áreas da exposição foram colocadas lupas para, ao auxiliar na exploração dos mapas, despertar a curiosidade do visitante através do aspecto lúdico do ato de procurar e descobrir. A cópia: uma parte dos mapas foi utilizada no formato de cópias em fac-simile, o que possibilitou um acesso direto ao material, em alguns casos ainda enriquecido com as lupas, mas sempre colocado em bancadas inclinadas ou horizontais, facilitando a visão e o ato de apoiar-se para examinar confortavelmente.

O educativo: a exposição foi montada possibilitando, em cada um dos seus segmentos, o desenvolvimento de projetos educativos dirigidos às diferentes faixas etárias que visitam o museu.

A coerência: todo o material utilizado como ilustração foi retirado de mapas do período abordado em cada um dos núcleos.

Módulos

\section{O início}

No saguão do museu, após o primeiro impacto causado pela beleza do espaço, iniciamos a exposição utilizando o conjunto de colunas e paredes, com sua aparência de troncos a entrecortar a visão, como suportes para os monstros (Figura 1) e barcos (Figura 2) presentes no imaginário dos viajantes da época, perpetuados nos mapas que adiante iríamos expor, para introduzir o percurso da exposição de uma maneira lúdica e convidativa. Do saguão era possível antever todo o primeiro segmento, com suas vitrines perfiladas ao lado do piso ocupado por uma carta náutica em grandes dimensões, tendo ao fundo o vídeo, com seus mapas ampliados em movimento, tudo somado ao som galático que "fugia" da sala.

2. A cosmografia dos descobrimentos: novos céus, novos mares e novo mundo

Este segmento ocupava um corredor escurecido, tendo, nas duas laterais, vitrines ocupadas por mapas e instrumentos de navegação do período. No ambiente azul relacionado às viagens e aos descobrimentos pelos mares, o ambiente era dominado pelas ilustrações - dos ventos (Figura 3), de cosmógrafos, e de uma caravela, tudo encimado pela Terra amparada por Júpiter e Juno. detalhe que interligava o todo era a ampliação gigante de parte de uma carta náutica colocada no piso (Figura 4), que convidava a navegarmos pelo segmento. O som galático e atemporal completava o conjunto de maneira a poetizá-lo. 


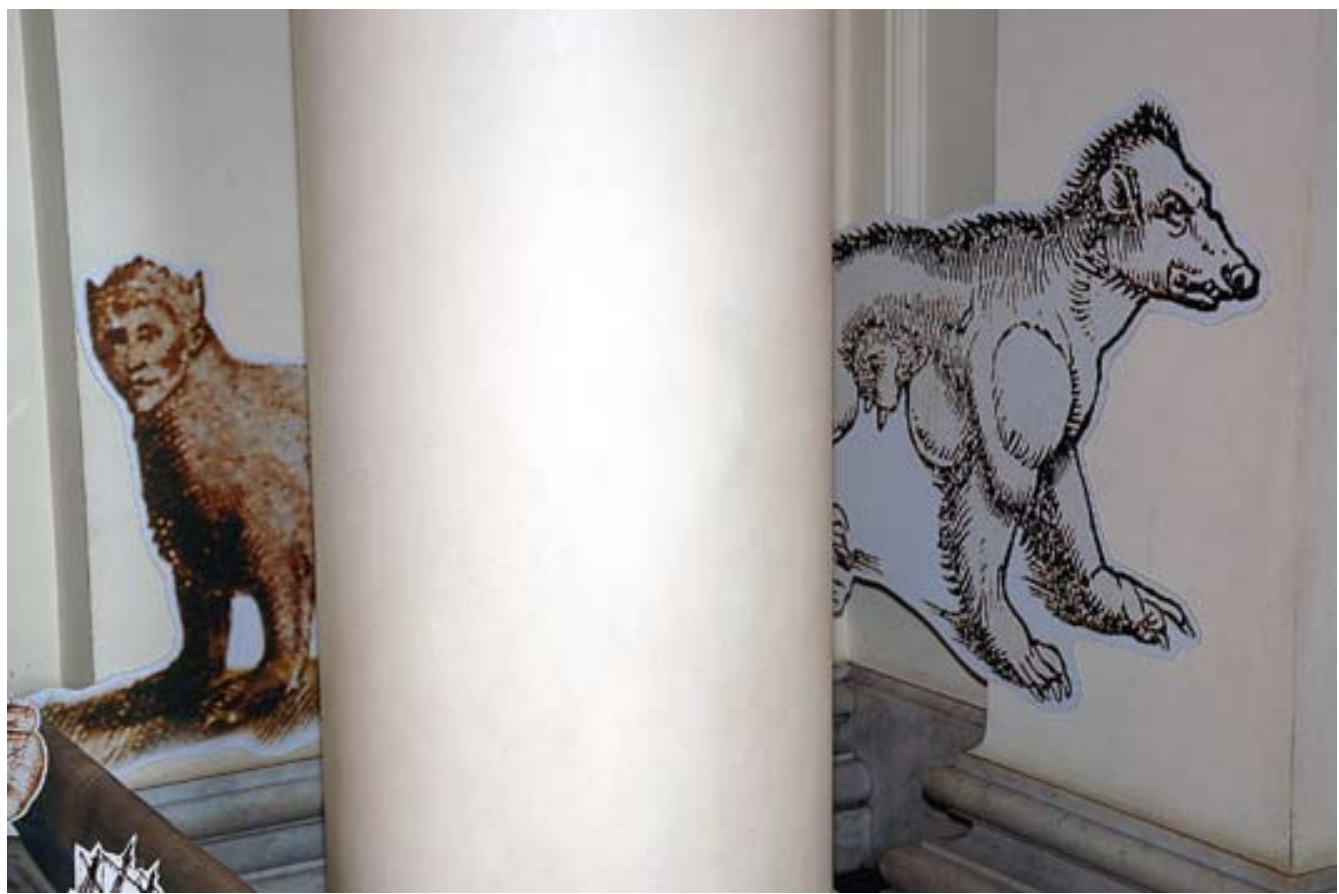

1 - Monstros espreitam o visitante no saguão do Museu Paulista. Fotografia de José Rosael.

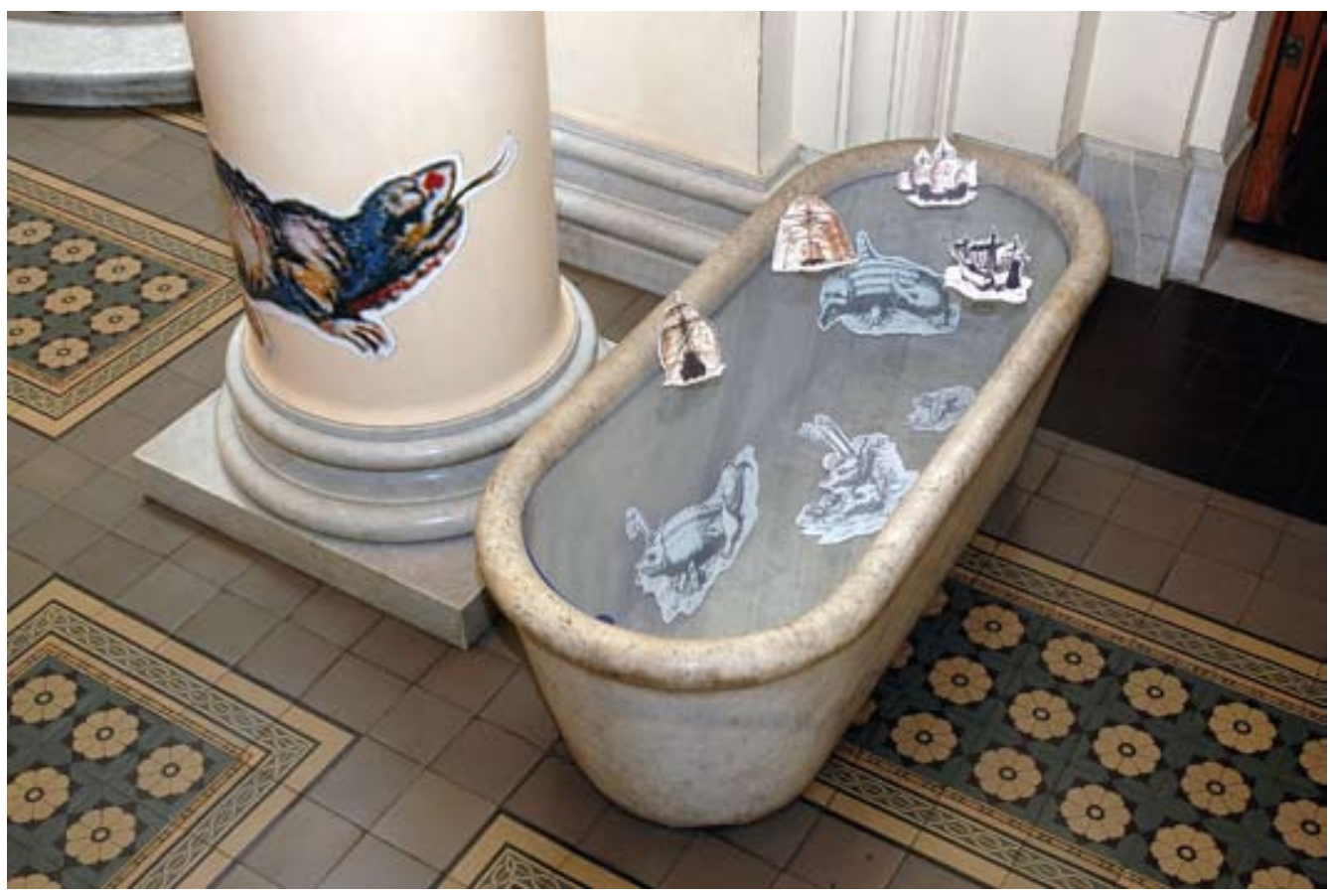

2 - Barcos e monstros marinhos em uma banheira de mármore no saguão do Museu Paulista. Fotografia de José Rosael. 


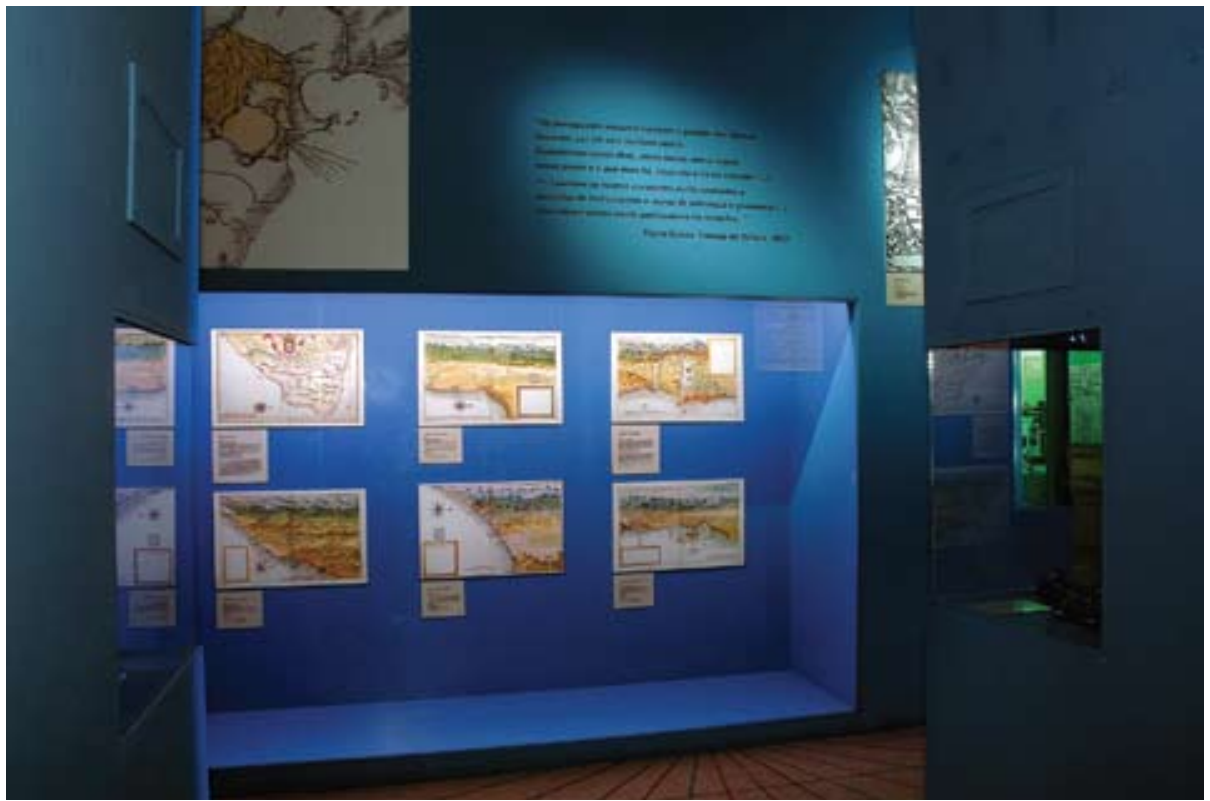

3 - Parte do segmento A cosmografia dos descobrimentos: novos céus, novos mares e novo mundo. Fotografia de José Rosael.

4 - Detalhe do piso, no segmento A cosmografia dos descobrimentos: novos céus, novos mares e novo mundo. Fotografia de José Rosael.

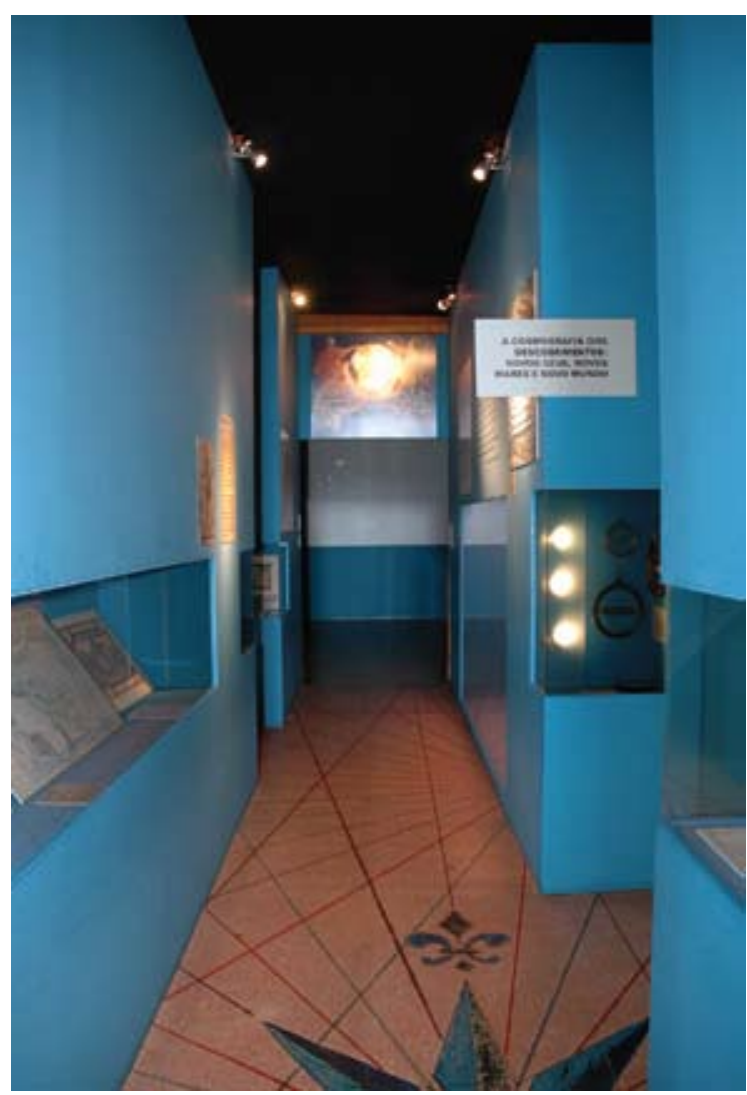

Anais do Museu Paulista.v. 17.n.1. jan.jun. 2009. 


\section{Desconstruindo os mapas}

Esta sala foi escurecida ao ser envolvida pelo seu azul-ultramarino; e não continha acervo material: uma instalação montada com elementos que exploram a criação e os objetivos dos mapas. $\bigcirc$ elemento dominante foi o vídeo (Figura 5), ladeado no espaço por três globos terrestres em posições invertidas e pela back-light com imagem de um mapa-múndi também invertido (Figura 6), com - Sul acima e o Norte abaixo, apontando que a representação habitual de norte e sul é uma questão de convenção cultural europeia, disseminada pela "naturalidade" de seus autores ocidentais. A luz da sala emanava dos próprios suportes - vídeo, globos, back-light - tudo "tonalizado" e "embalado" pelo mesmo som da sala anterior, completando e interligando o conjunto.

4. Do campo ao gabinete: as cartas terrestres dos engenheiros militares

Esta sala também é de descobrimentos. Agora, no descobrimento do interior do continente, o verde é dominante, matizes de verde causados pela iluminação, tendo ao fundo um mural baseado em um desenho de Thomas Ender (Figura 7), na região do Vale do Paraíba no início do século XIX. Exploramos o trabalho do engenheiro

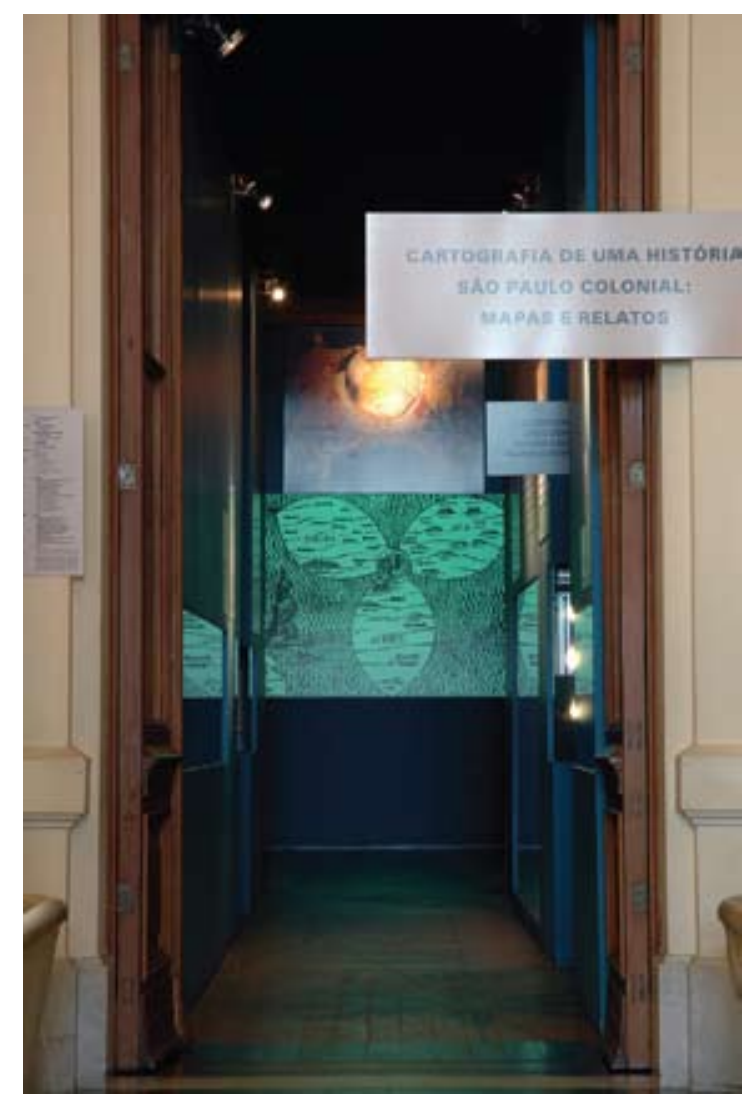

5 - Projeção do vídeo vista a partir do corredor de acesso ao segmento Desconstruindo os mapas. Fotografia de José Rosael 


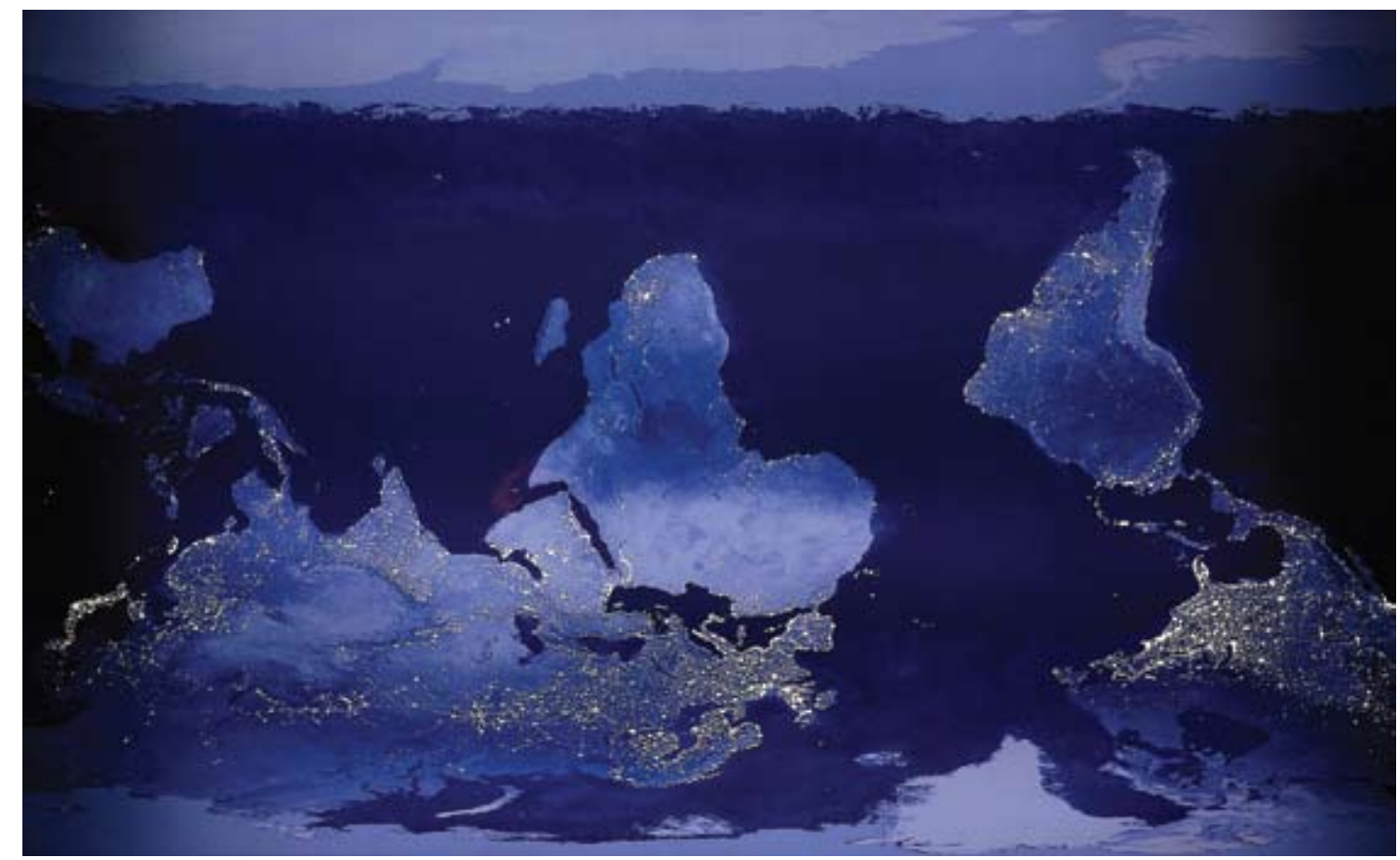

6 - Back-light de um mapa-múndi, no segmento Desconstruindo os mapas. Fotografia de José Rosael.

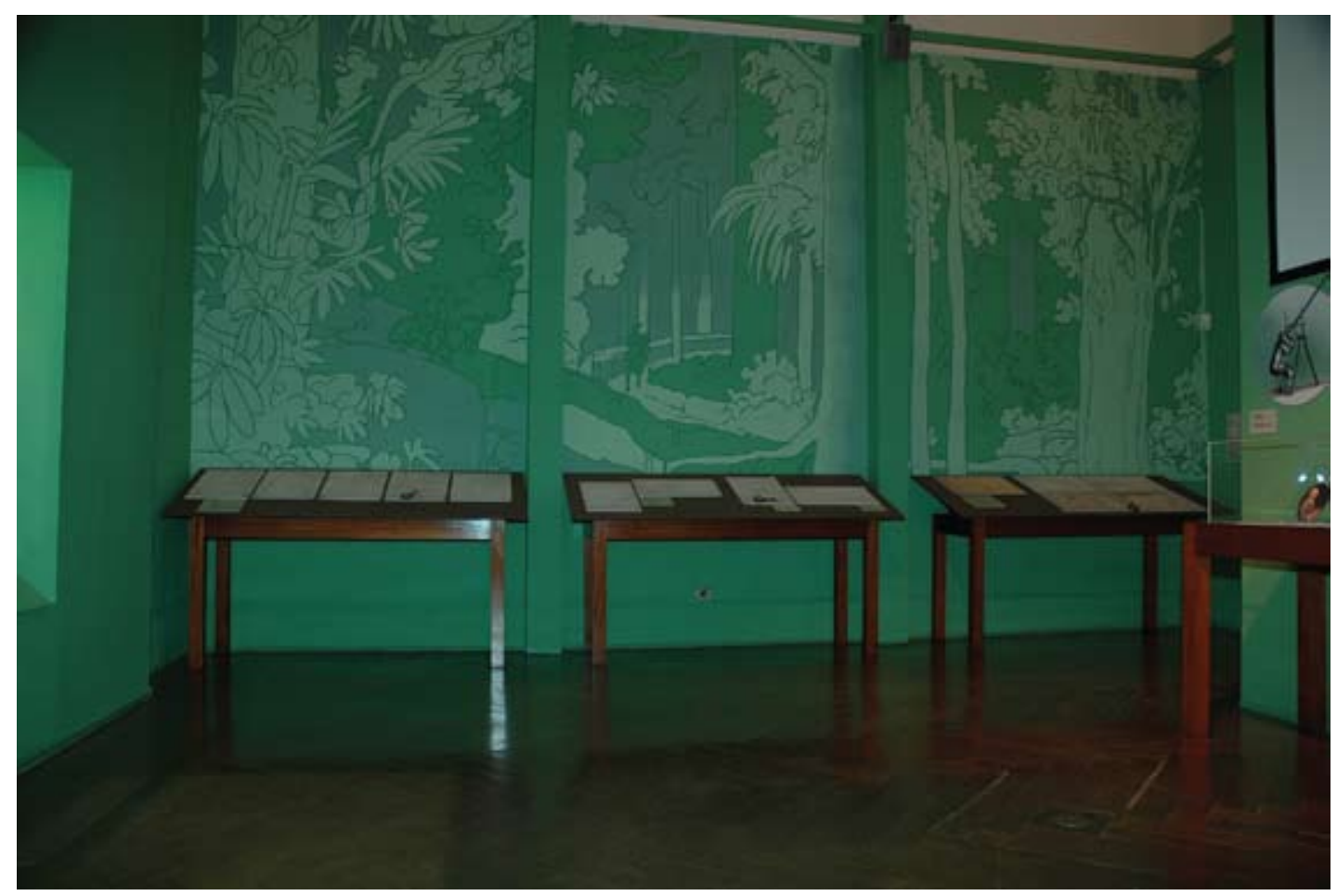

7 - Mural baseado em um desenho de Thomas Ender e pranchas com esboços e mapas, no segmento Do campo ao gabinete: as cartas terrestres dos engenheiros militares. Fotografia de José Rosael. 
militar em duas vitrines iniciais, frente a frente, uma com os instrumentos e orientações de trabalho (Figura 8) e a outra com os códigos de leitura dos mapas (Figura 9). 0 resto da sala é a realização do seu trabalho: um conjunto de mapas, lado a lado, do esboço ao mapa final, em pranchas reclinadas e com lupas (Figura 7) para auxiliar a leitura - um convite à exploração, mostrando todo o trabalho de produção de um mapa. Em uma vitrine ao lado, com um trecho de texto descrevendo a viagem pelo rio e o desenho do barco (Figura 10), ambos apresentados no conjunto de mapas, foi feita uma montagem. $\bigcirc$ ambiente é completado com uma vitrine com instrumento - um relógio de sol - e ilustrações de medições; ao alto, a imagem em movimento de um eclipse da lua de Júpiter (Figura 111).

\section{5. $\bigcirc$ gabinete de desenho do engenheiro militar}

No subsolo da área de exposições, um pequeno espaço, foi montada uma simulação do gabinete de um engenheiro militar (Figura 12). Não se pretendeu montar um ambiente real, mas, com objetos antigos e modernos somados a cópias de mapas da época e réguas, pincéis e tintas, sugerir o que seria o seu espaço de trabalho, o universo com que lidava.

\section{Definição dos confins: o uso político dos mapas}

Esta era uma sala sem adornos ou jogos cênicos, assumidamente fria, na cor ocre. Toda a atenção voltou-se para os mapas e para a utilização política

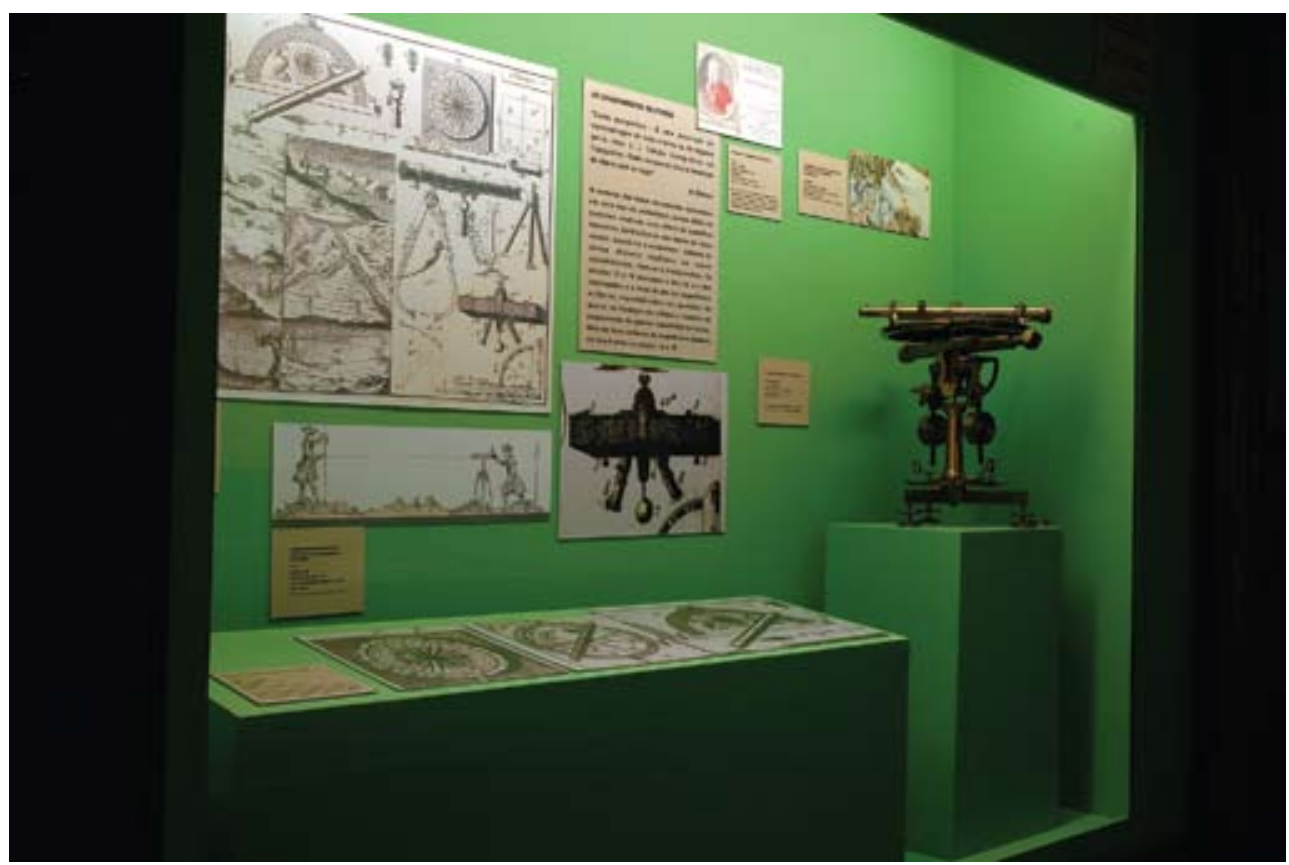

8 - Vitrine com instrumentos e orientações de trabalho, no segmento Do campo ao gabinete: as cartas terrestres dos engenheiros militares. Fotografia de José Rosael. 


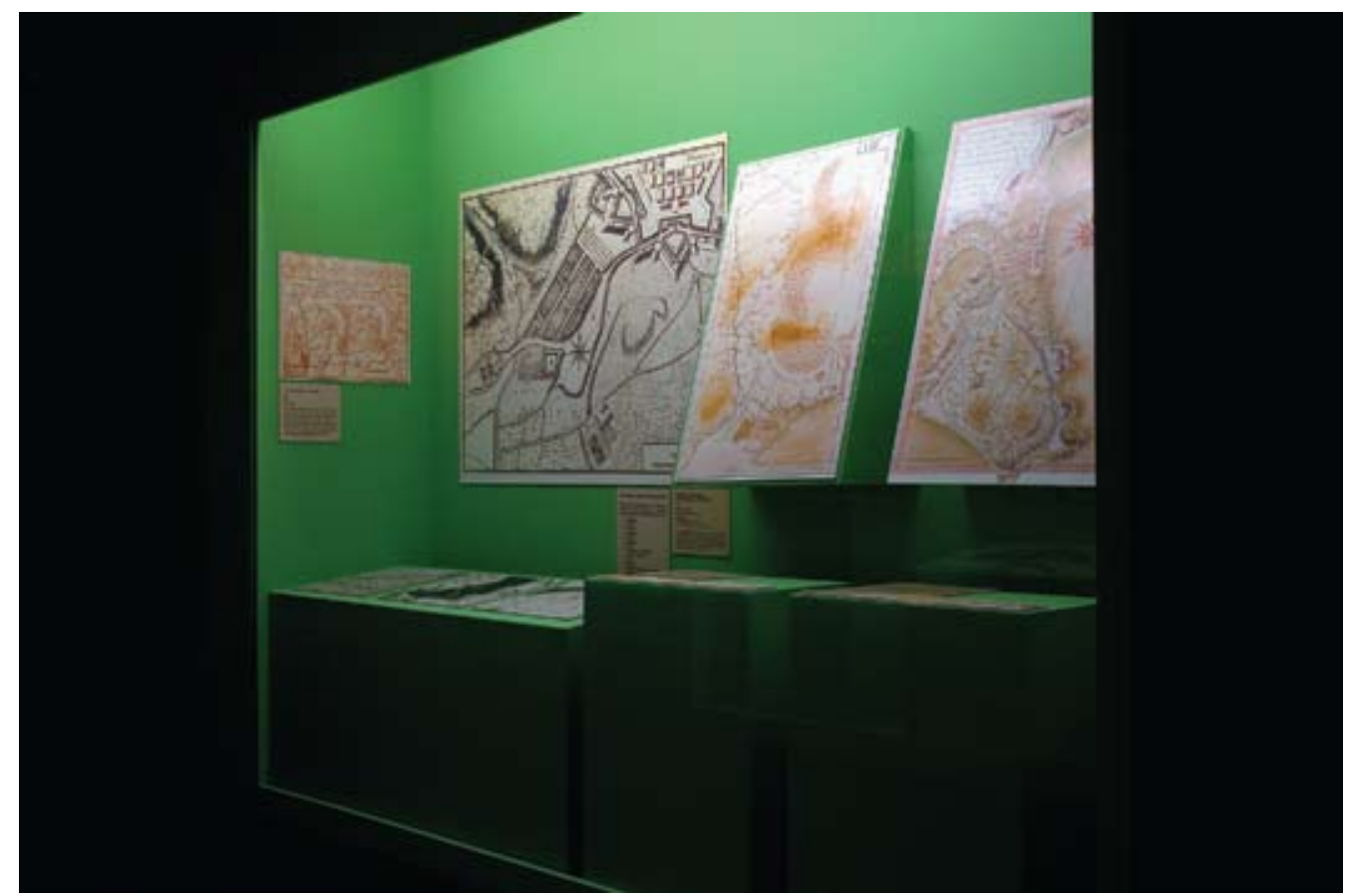

9 - Vitrine com os códigos de leitura dos mapas, no segmento Do campo ao gabinete: as cartas terrestres dos engenheiros militares. Fotografia de José Rosael.

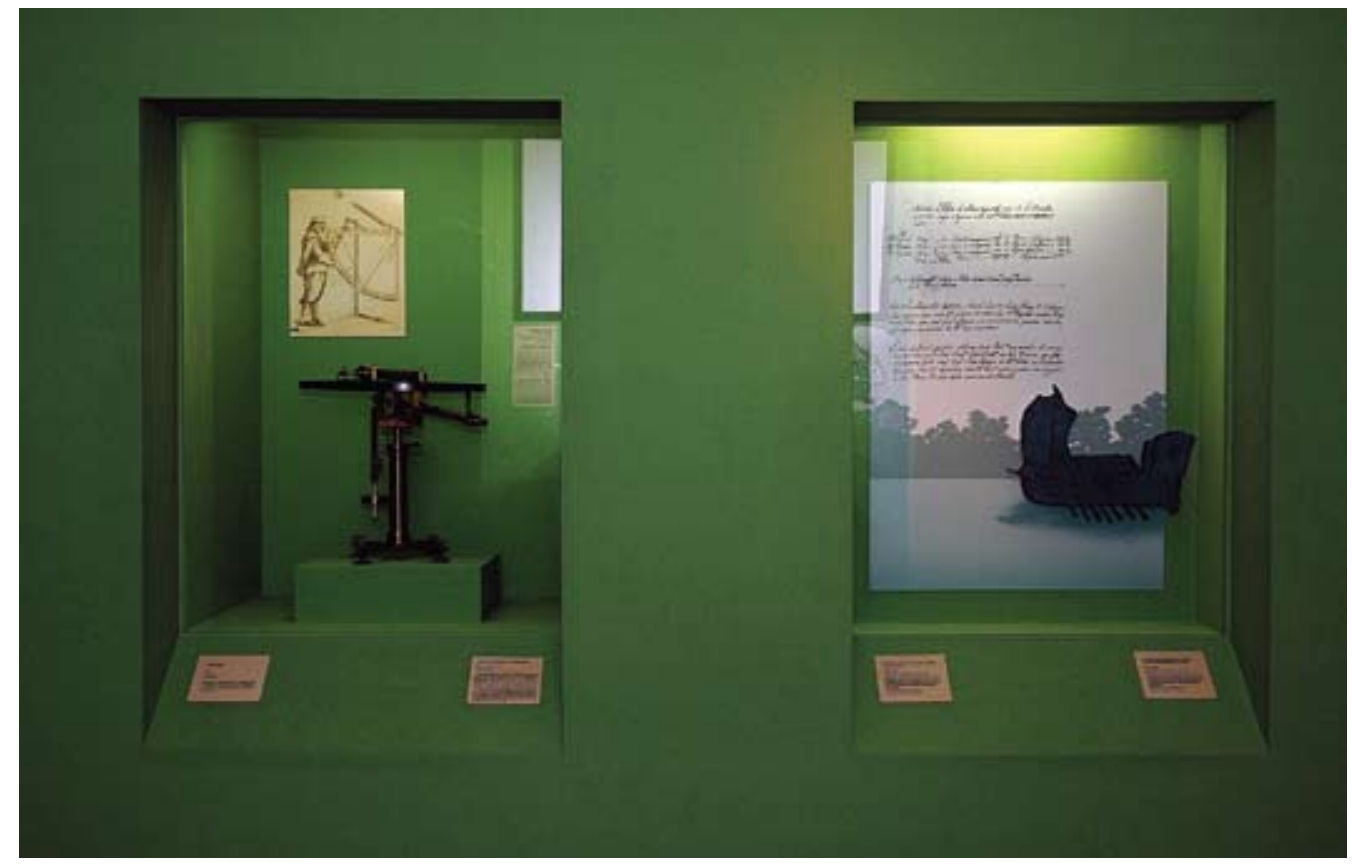

10 - Vitrines com instrumento e montagem com imagem de barco e texto, no segmento Do campo ao gabinete: as cartas terrestres dos engenheiros militares. Fotografia de José Rosael. 


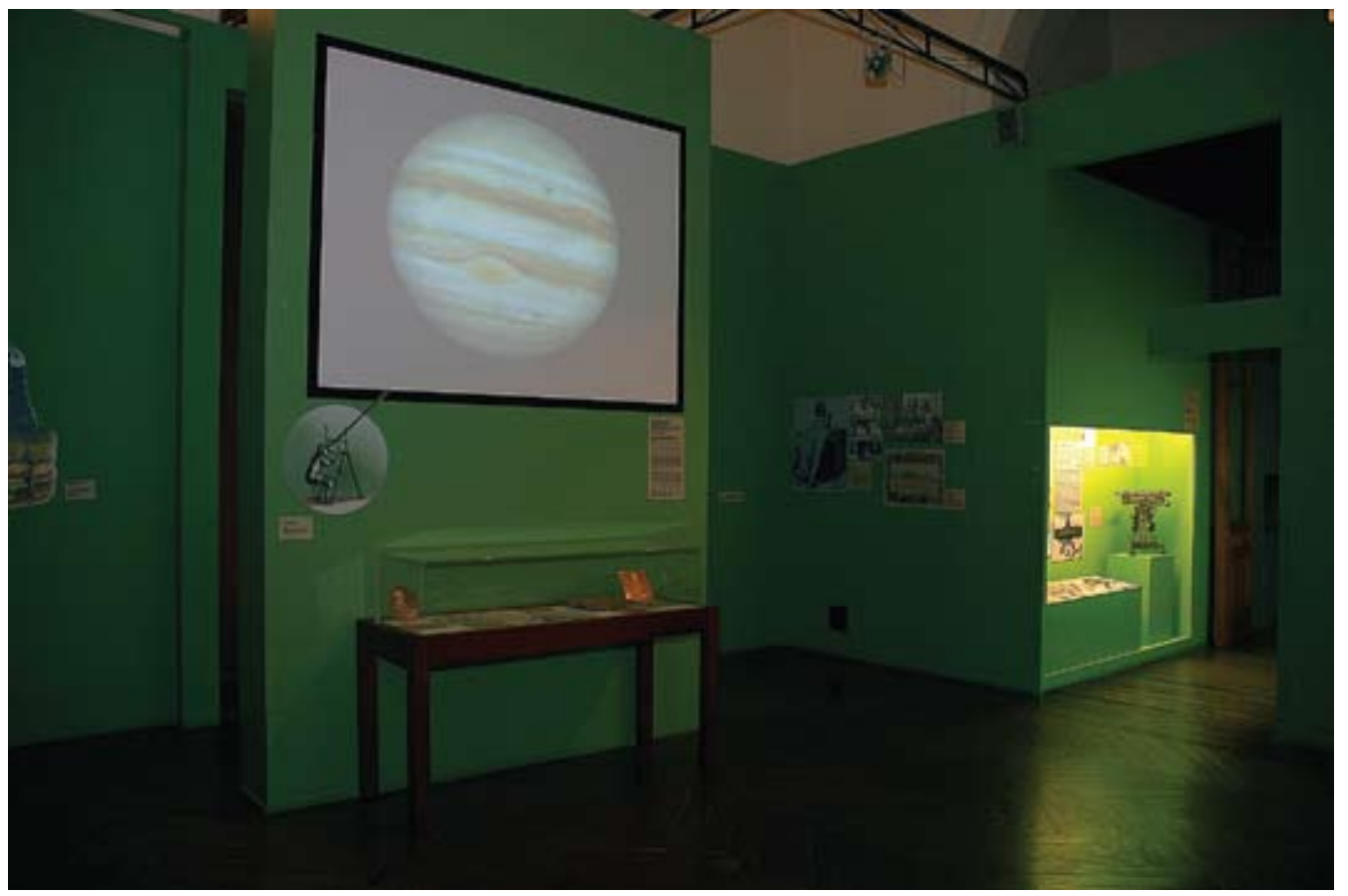

11 - Projeção no segmento Do campo ao gabinete: as cartas terrestres dos engenheiros militares. Fotografia de José Rosael.

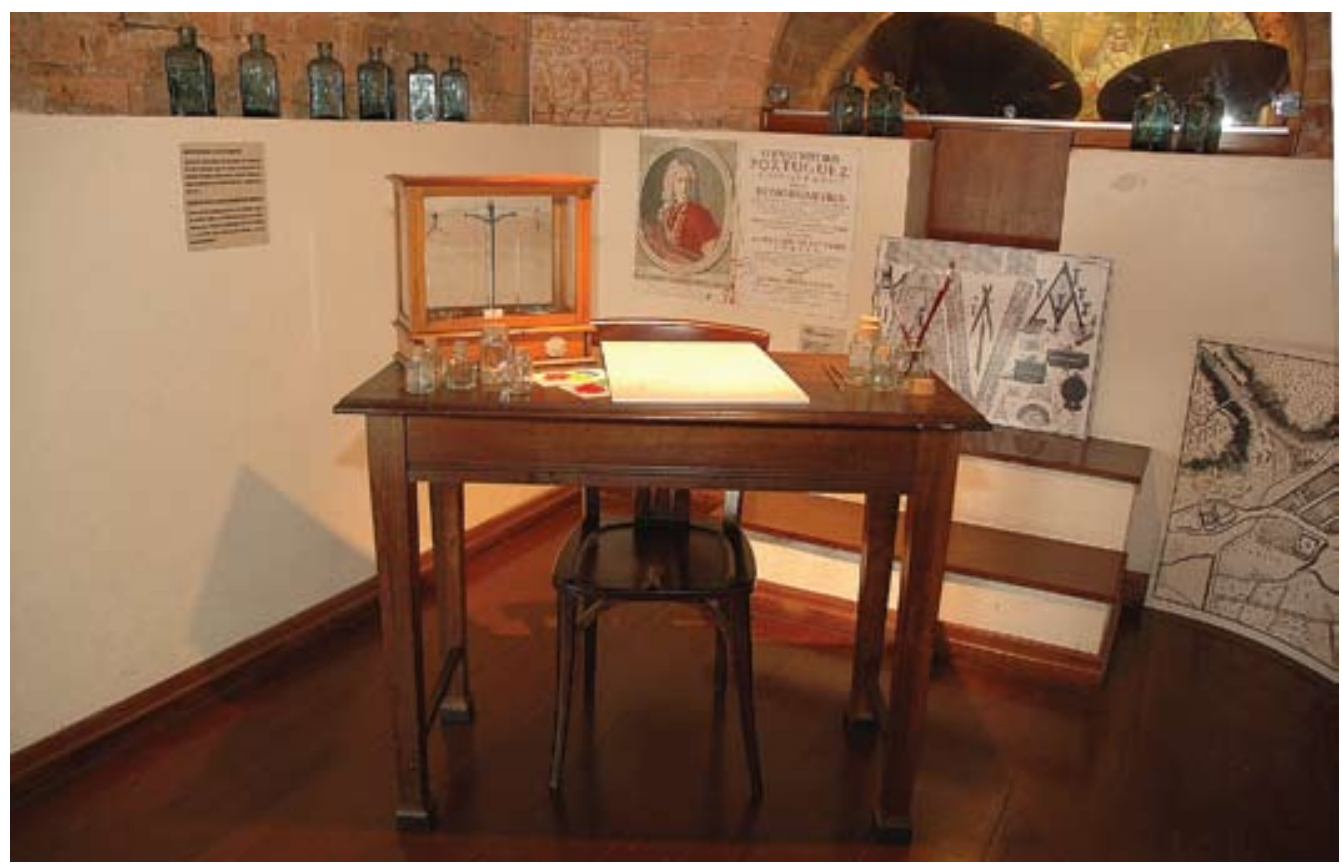

12 - O Gabinete do Engenheiro Militar. Fotografia de José Rosael. 
desses pelos governos de Portugal e Espanha, papel que foi sublinhado utilizando-se, ao lado dos mapas de época, outros criados sobre fotografias de satélites do Inpe, tornando mais a fácil leitura de tratados e as localizações de fortes, vilas e caminhos. As grandes telas comemorativas de descobrimentos e fundações, somadas ao pelourinho e ao cruzeiro, ambos grandes objetos de pedra, compõem o entorno da sala (Figura 13) centralizada nos mapas colocados em vitrines ou em pranchas reclinadas com lupas (Figura 14), convidando à exploração.

\section{Caminhos e caminhantes: as vivências no sertão}

A sala verde era o mato, a floresta a ser percorrida, os mapas em criação, rasurados, manuscritos. $O$ canoão no centro da sala é o elemento dominante (Figura 15). Ao fundo, três telas apresentavam as maneiras de percorrer o sertão, pelo mato ou por rio, atividade destacada em cada tela por um recorte fotográfico temático. Um conjunto de objetos trabalhava o cotidiano desses viajantes. Paulistas em tamanho natural (Figura 16), ampliações de desenhos de Thomas Ender, guardavam a sala, ao som da benção das canoas, do barulho do rio, de cantos de índios.

8. O território em rede: vilas e cidades no desenho das fronteiras

Uma segunda sala - sem adornos ou jogos cênicos e, também, assumidamente fria - onde a atenção era focada nos mapas. Produzidos pelo

13 - Vista geral do segmento Definição dos confins: o uso político dos mapas. Fotografia de José Rosael.

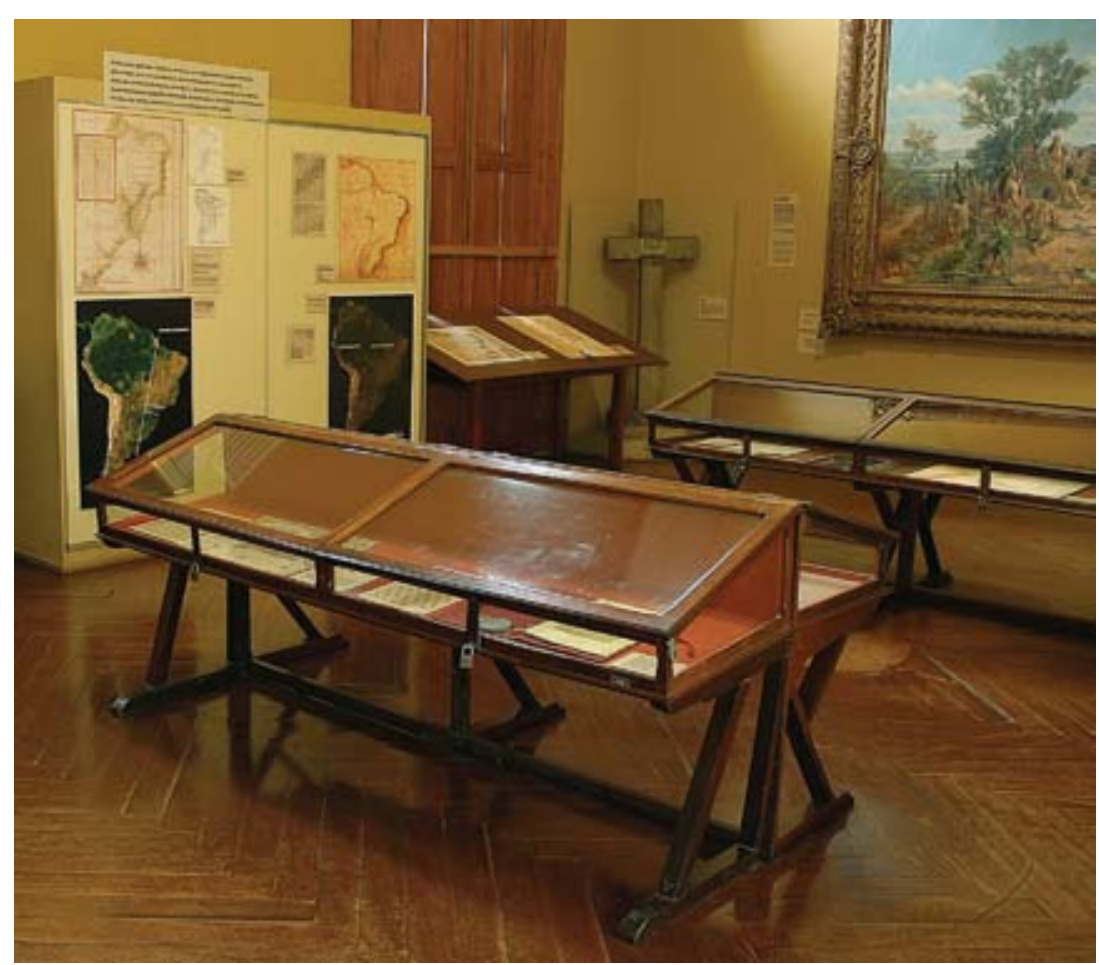




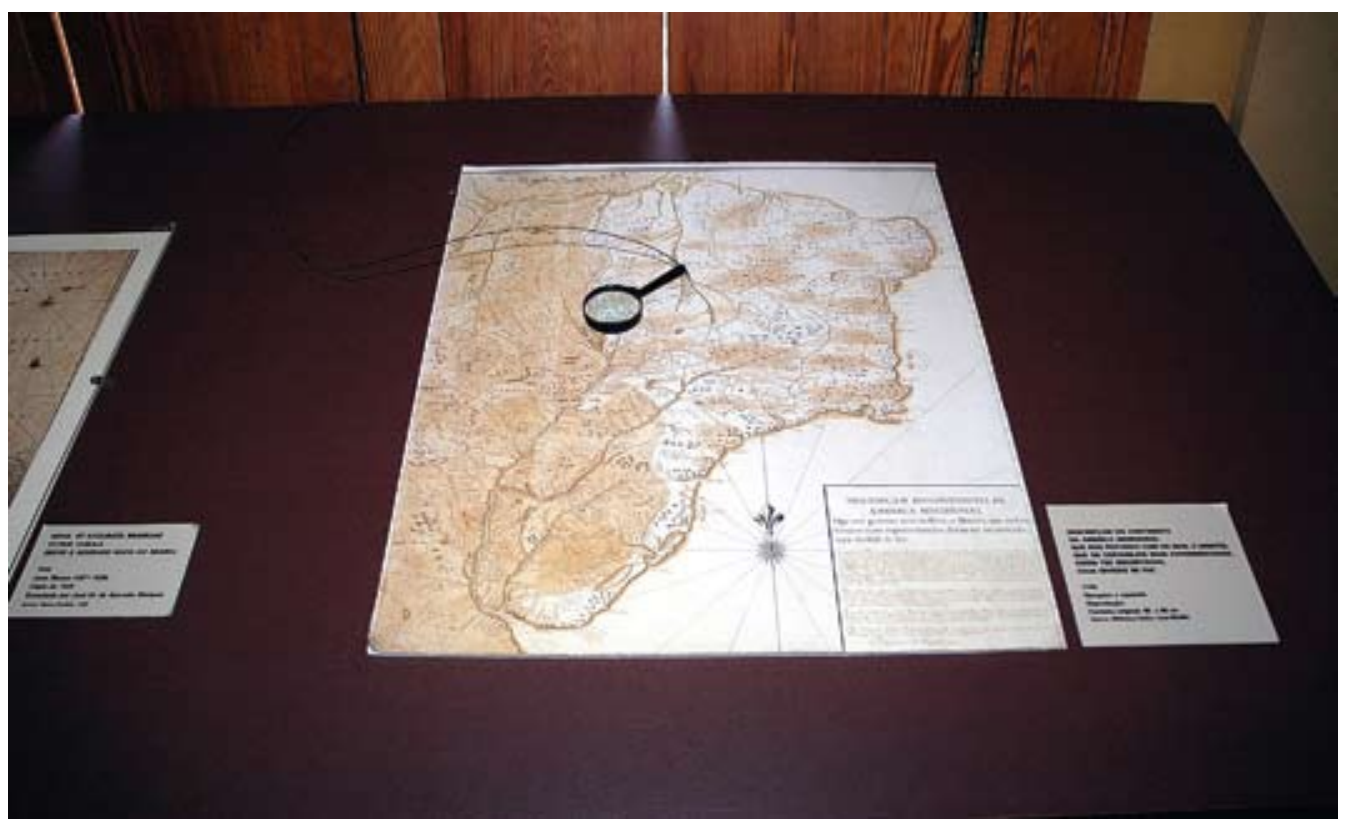

14 - Mapa e lupa, no segmento Definição dos confins: o uso político dos mapas. Fotografia de José Rosael.

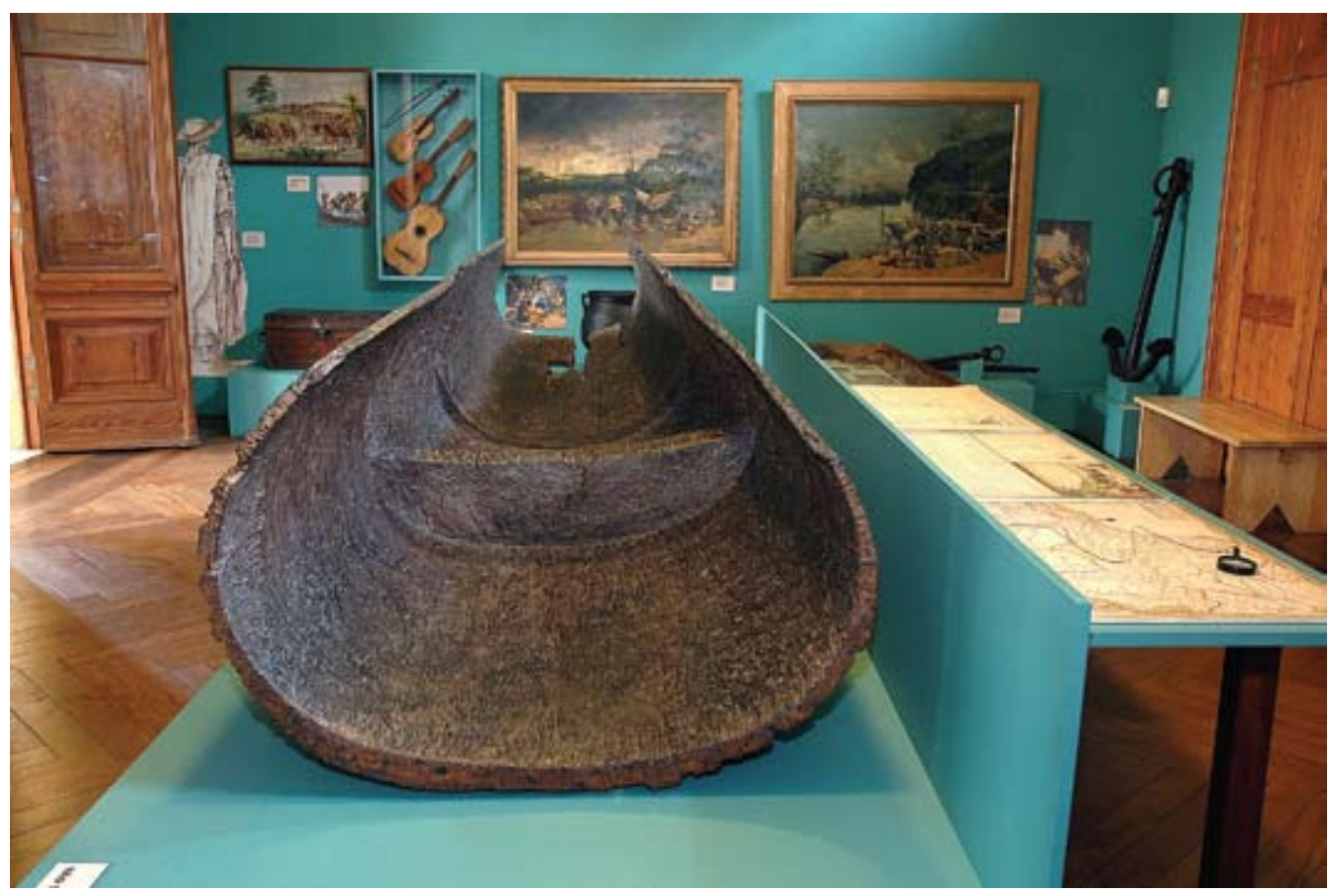

15 - $\bigcirc$ canoão e parte do segmento Caminhos e caminhantes: as vivências no sertão. Fotografia de José Rosael. 


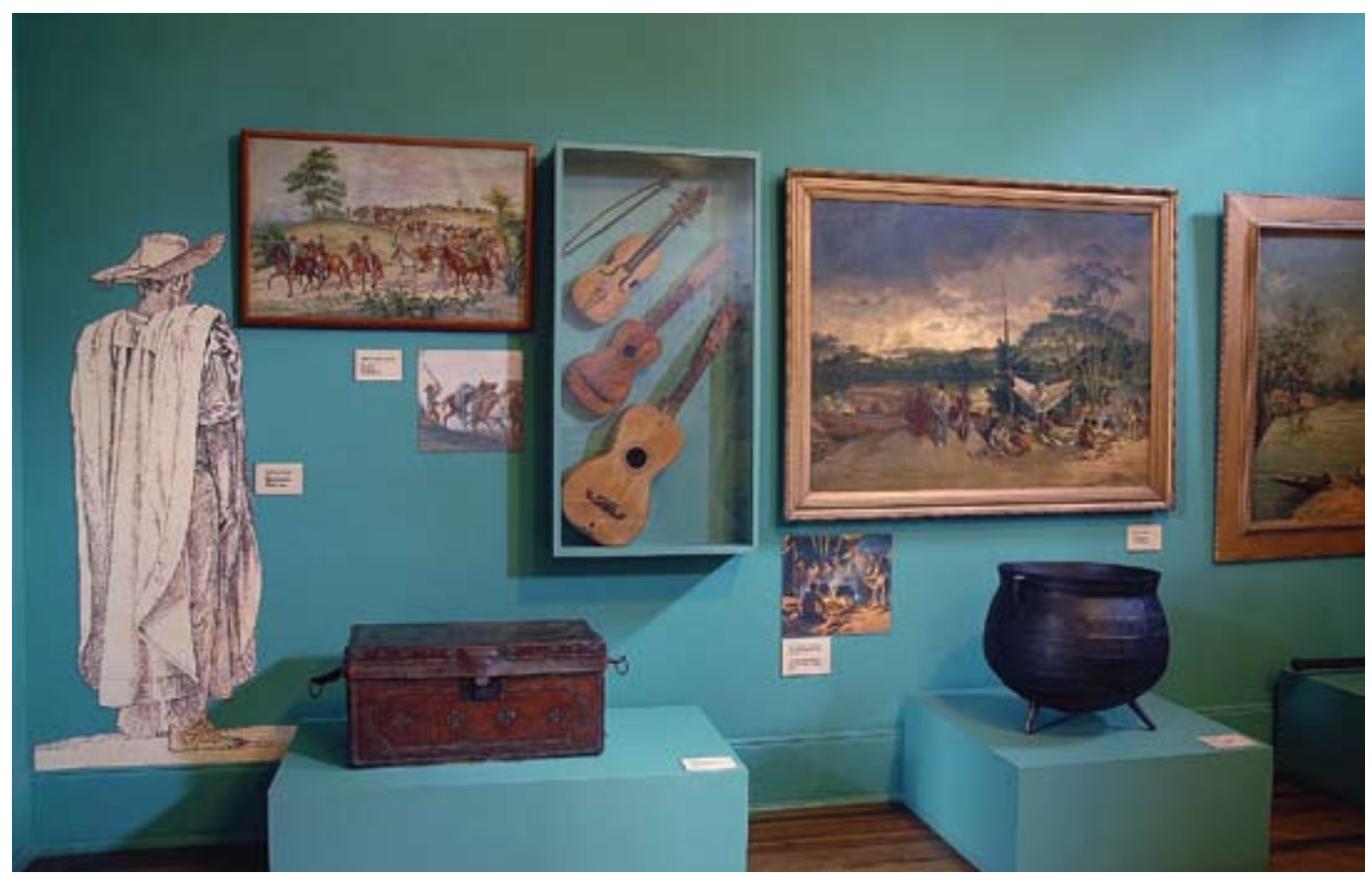

16 - Detalhe do segmento Caminhos e caminhantes: as vivências no sertão. Fotografia de José Rosael.

Inpe sobre fotografias de satélite, eles eram os elementos dominantes, sempre tendo próximos os mapas que orientaram sua execução, como o mapa (desenhado) com o Tratado de Tordesilhas (Figura 17), e tendo um fac-símile da Carta do Brasil (1590), de Luís Teixeira, colocada abaixo em uma vitrine. Na segunda parte, três mapas, com parte da América do Sul na área do Atlântico - que hoje conhecemos como as regiões Sudeste e Sul do Brasil -, mostrando as povoações e caminhos em formação, na área ocupada por São Paulo, em três momentos do Brasil Colônia, mas não apresentando como referência o desenho político atual dos estados brasileiros, mas apenas um verde sem delimitações.

\section{Maquete da Cidade de São Paulo no Século XIX}

trabalho na sala em que está a maquete da cidade de São Paulo é uma pequena intervenção, resumindo-se à colocação de uma plotagem ampliada de uma vista (Figura 18), que se somou a outras duas já existentes no local e que representam as entradas e saídas da cidade em meados do século XIX.

Conclusão

Desenvolvemos o projeto museográfico da exposição Cartografia de uma história - São Paulo Colonial: Mapas e Relatos buscando tornar interessante, 
aos públicos que visitam o Museu Paulisła, a produção e o uso dos mapas, algo aparentemente difícil para um leigo. A proposta era conquistar o olhar e o tempo do visitante para podermos iniciar o diálogo silencioso e solitário, mesmo que com a participação de outros visitantes.

A museografia trabalhou com a ideia da descoberta. A exposição, em seus primeiros segmentos, trata disso - a descoberta dos mares, dos continentes, dos interiores das terras. Estendemos a proposta a toda a exposição: descobrir sempre tem um delicioso sabor lúdico, o ato de conhecer coisas novas, ou um jeito de ler de uma nova maneira coisas já conhecidas.

As lupas, colocadas ao lado de mapas dos diferentes segmentos da exposição, foram um elemento-chave no jogo do descobrir, pois, além de auxiliarem

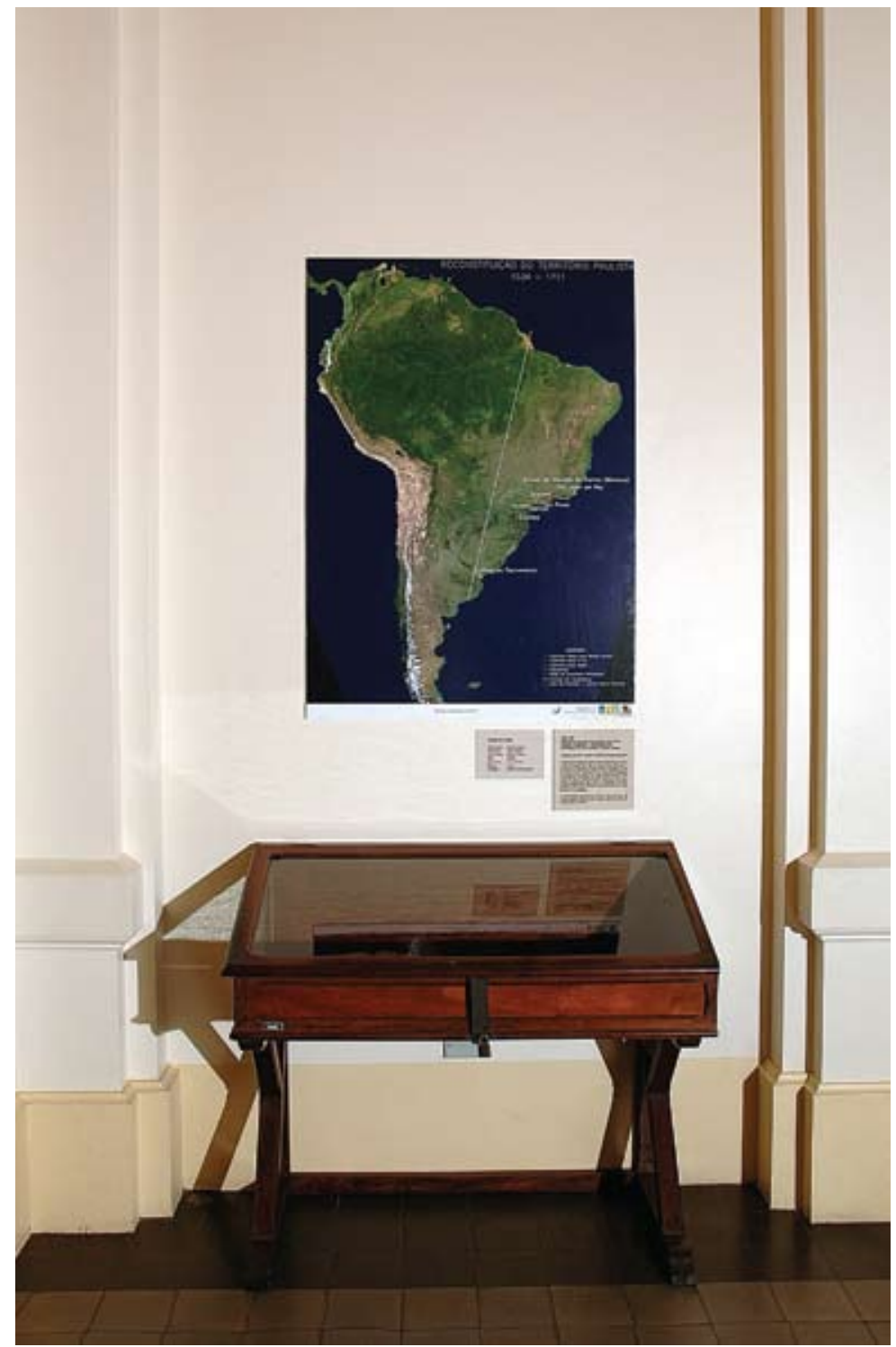

17 - Mapa produzido pelo Inpe para o segmento $\bigcirc$ território em rede: vilas e cidades no desenho das fronteiras. Fotografia de José Rosael. 
18 - Parte da maquete, no segmento Maquete da cidade de São Paulo no século XIX. Fotografia de José Rosael.

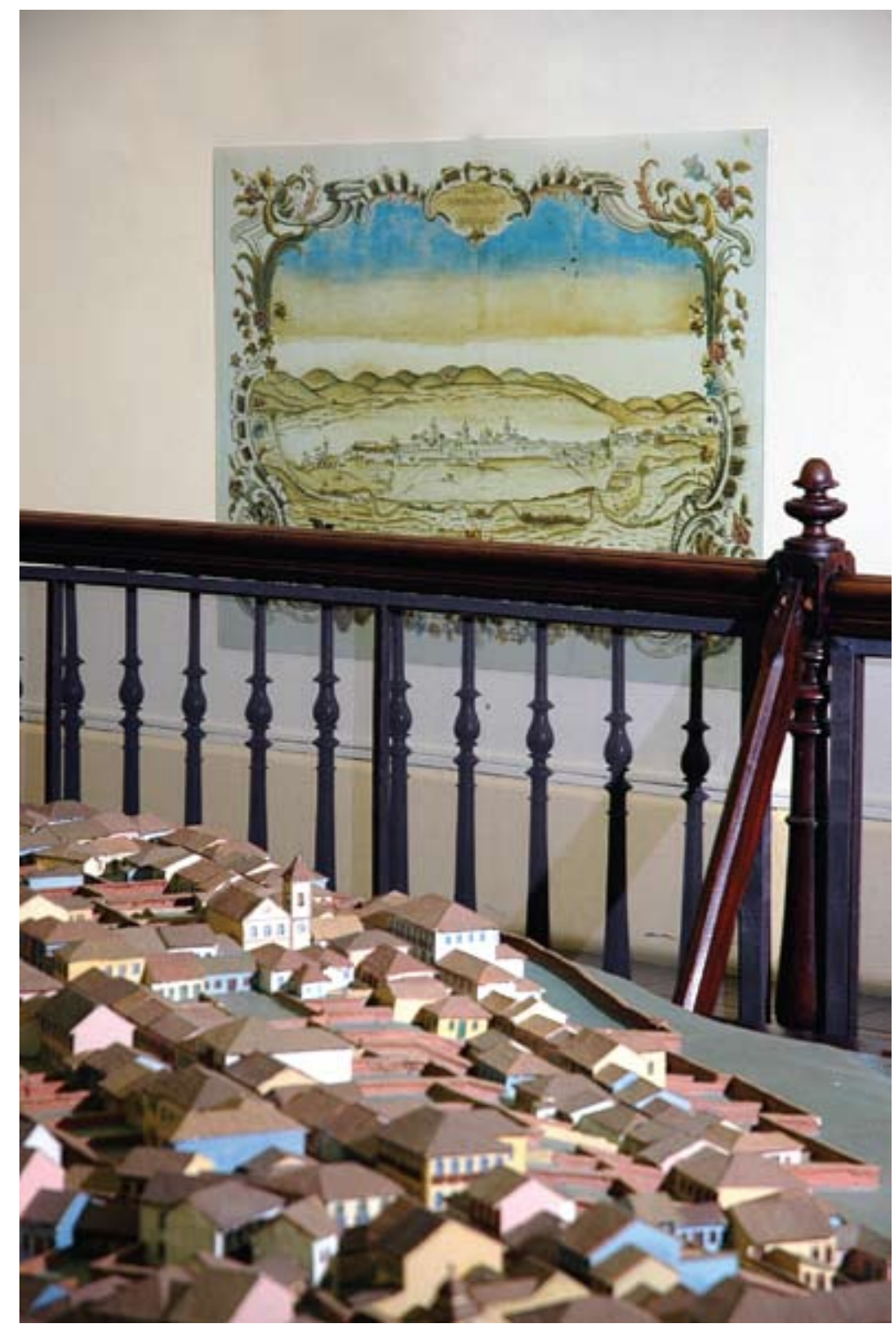

na exploração do mapa, levavam o visitante a olhar com mais atenção aos outros elementos que compunham a sala. Os suportes - pranchas reclinadas, mesas e vitrines baixas -, e que eram um convite ao debruçar-se para examinar mais de perto.

As cores, a iluminação, os suportes adequados e os outros recursos sonoros e visuais possibilitaram criar ambientes envolventes ou mais frios e cerebrais, conforme a temática da sala. Mas, em todos os segmentos, a atenção foi centralizada na análise dos mapas, a razão de ser desta exposição. 


\section{REFERÊNCIAS}

GONÇALVES, L. R. Entre cenografias: o museu e a exposição de arte no século XX. São Paulo: Edusp, 2004

HORNE, D. "Reading" Museums. In: Museums 2000. Politics, people, professionals and profit. London: Patric Boylan; - Routledge, 1992.

O'DOHERTY, B. No Interior do Cubo Branco: a ideologia do espaço da arte. São Paulo: Martins Fontes, 2002.

PEARCE, S. Objects as meaning: or narrating the past. In: Objects of knowledge. London: Athone, 1990.

RÚSSIO, W. L'interdisciplinarité em muséologie. Museological Working Papers, Icofom/SHM, Stockholm, n. 2, p. 58-59, 1981.

Artigo apresentado em 8/2008. Aprovado em 12/2008. 